\title{
AUGMENTING STUDENTS' SPEAKING SKILL THROUGH VLOG AS AN INNOVATION IN LEARNING
}

\author{
Ainan Salsabila \\ Universitas Muhammadiyah Jakarta (UMJ) Indonesia \\ Email: ainansalsabila31@gmail.com
}

\begin{abstract}
In this era of globalization, technology media has become an important role that can be used in the world of education. Especially vlog can be used as content to explore creative potential for everyone to augment speaking skills. Vlog defines as the documentation using video component as a medium media to record that they want to talk about it. The purpose of this research article of the innovation in learning through vlog is to augment students' confidence speaking skill in their classroom. The data of this research used case study in the form of descriptive analysis using qualitative research methods. Data collection techniques were collected by observation of eight grader graduate in SMP Darul Ulum Depok. The results of this research revealed that after the students conducted the vlog, the students successfully in the criteria points for improving speaking skill and they more enjoy in speaking performance. Besides, the use innovation through vlog can enhanced students' fluency, pronunciation, vocabulary, and good performance.
\end{abstract}

Keywords: innovation; vlog; speaking skill

\section{Introduction}

There are various ways to produce English Speaking skills. The basic way is to use a method that makes students feel comfortable, interesting, and relax. This can reduce the impact of student absence from language classes. In today's era, teachers feel the need to make an explanation design with a method that is introduced to any generation, especially the younger generation which certainly cannot be separated from it, namely the media. In essence, students will master more quickly than the previous method that has been taught by the teacher.

Speaking ability is important that must be mastered in English Skill (Lidya \& Amir, 2017). Because speaking is like a bridge for people communication between all human in the different country in the world. Through speaking, people can share their ideas, opinion, feelings, and information by using a set of words that contain various kinds of conditions. Most people think that speaking is the most difficult of various skills, such as writing, listening, and reading. And some of the students also don't like speaking, because they already imagine the difficulty of pronouncing words in English. And even became insecure about what they wanted to say. One aspect of improving the speaking class, the teacher should be given to them an engaging activity. To make it easier for them to build communication through verbal in practice. When they practice it

\begin{tabular}{ll}
\hline How to cite: & Salsabila, A. (2021) Augmenting Students' Speaking Skill through Vlog as an Innovation in Learning, \\
& Syntax Idea, 3(8), https://doi.org/10.36418/syntax-idea.v6i8.1405 \\
E-ISSN: & $2684-883 \mathrm{X}$ \\
Published by: & Ridwan Institute
\end{tabular}


in front of their friends or other audiences, the students don't need to memorize it again in the form of text. The students will immediately speak with structured sentences fluently and clearly spoken directly from their mind.

Speaking describes an activity in the form of social, multi-sensory, speech event, which the topic is not assumed through prediction. Speaking is inextricably linked to learning a language, thus students should focus on mastering this component of speaking. According to Chaney in Kayi (2006, p. 1) stated that speaking is the activity of creating and sharing meaning by using of verbal and nonverbal symbols in a range of circumstances (Cited by (Andini, Eun, Khramova, \& Żok, 2020). Speaking is an important aspect of language acquisition. It is necessary for the speakers to produce the target language in spoken form. In addition, according to Scott Thornburry (2006) stated that speaking is social elements to people interacts by expressed through their thoughts, emotions, attitudes and opinions (Matius, Haryanto, \& Salija, 2018). All they can tell is in the classroom when the learning speaking process.

These days a lot of speaking problems. Since, English is a Foreign Language in our country. Most students especially in Junior High School students are not familiar with it cited by (Anggraini, 2018). The learning of speaking becomes a lot of problems because there are many words errors in terms of pronunciation. Especially on the spelling of words that are different from Indonesian itself. Usually this problem occurs when students rarely listen to English sentences or vocabulary spoken directly by the native speaker. The students can listen to native speakers on YouTube, podcasts, music and so on. To check whether what the people say by correctly in pronounced. Besides, most of teacher have focus on textbooks when designing materials. It is very difficult for students may not have enough in opportunities to practice speak English in the Classroom (Butar, A. T., 2019). Speaking is a process of communication about our self. In speaking, someone certainly has problems related to individuals or groups and fix them together.

In speaking can produce a relationship between speaker and listener. This has become an important aspect of communication that can be a bridge for crossing cultures among the countries. In addition, as the second language of the mother tongue, it must be prioritized with various consequences on their spoken language proficiency. There are several components that must be mastered in speaking skills, those are:

a. Pronunciation

Is the ability to produce easily comprehensible articulation. There are 3 basics in teaching pronunciation. The first is Exhortation such as the mimic to make such a sound without explanation. The second is speech training such as exercises to practice particular sounds rhythm and intonation, and the third is practical phonetics.

b. Grammar

Argues that language grammar is a description of ways in which words can be transformed and conjoined into sentences in that way (Putri, 2018). Or the other definition of grammar is a set of logical and structural rules that have the composition of sentences, phrases and words in any given natural of language. 
c. Fluency

Is the smoothness with the sounds, syllables, and phrases in the speaking. That the most prominent one's skill in speaking. In the process of teaching and learning, if the teacher wants to test students' fluency, the teacher allows students to express themselves openly without disruption (Marzuki, Jabu, \& Basri, 2018).

Those are basic speaking skills in teaching the speaking that the teacher must be mastered to deliver to their students. In the teaching and learning speaking, the teacher must conduct a classroom research in their class, to observe the students problems in their lesson. English teachers ought to be an innovative in teaching speaking. The teacher can create the appropriate atmosphere to augment students speaking skill by using one media to help success in the student learning process (Rizqiningsih \& Hadi, 2019). Using the video blog, or what is known as vlog in various circles, can be an alternative media that can be used in any condition to enhance students' speaking abilities in the easily to express themselves without feeling stiff and tense. Students will feel more enjoy the language class in this speaking.

Learning media are known as teaching aids, then known again as audio visual aids (visual/hearing aids). And now the term instructional is commonly used in the world of education as a tool to assist teachers in realizing effective learning situations (Sumiharsono \& Hasanah, 2017). Vlog it gives numerous reviews for students. It combines video, audio, picture, informative content, exciting approaches to deliver, expression and emotion. (Mandasari \& Aminatun, 2020) And as we known also, using vlog can show their ability in the action. So it can help students to relate the interaction relationship in trust and increase in verbal communication.

States that vlog is one of the teaching media that is becoming a trend today (Lingga, Yulianti, \& Ningsih, 2021). Besides, According to (Sugiono \& Irwansyah, 2019) Stated that vlog is a type of digital media that features an individual monologue about personal experiences or thoughts. Vlog can significantly improve students' speaking skills. It can destroy students and encourage students' joy in accessing the learning process. They will easily interact with all their abilities related to their environment. In addition, students get to build up their breadth in increasing their learning progress. Using vlog can make students interested in learning which will make it easier to understand better in honing speaking skills.

In this era, vlog are a challenging thing that must be adopted for language learning, especially in speaking. There are students' impressions in learning though vlog in previous researchers. (Saputro, Tafsirudin, \& Farah, 2020) researched by conducting interviews with students. There were several responses from students related to vlog. The first, doing vlog can be anywhere and anytime, second, speaking using vlog make enjoyable, because the students can express their feelings freely with in a structured manner, and thirdly, vlog help them support their speaking skills with very motivating learning in speaking. In students' perception, it is felt that vlog 
are very effective in growing the emergence of student motivation in speaking skills that need to be redeveloped.

The Several studies have investigated the use of vlog in the teaching of English as a second language, with a variety of topics under consideration. The relation between one study and the next is that they all use Vlog as a learning medium, although for different goals. The first research is carried out by (Saputro et al., 2020) from Univesitas Malang Indonesia. They stated that vlog can increase the students' accuracy in speaking fluency and complexity. Vlogging for language learning is also talked to be more enjoyable than traditional classroom language study. The application of this study have the aims that was to examine the use of Vlog in increasing students' oral language production using the complexity, accuracy, and fluency by using a speaking test of interviews as data collection devices. The results of them study conclude that using vlog in the study got has a positive impact on learning and may even provide a superior learning opportunity.

The second research is carried out by (Rahayu, 2018) from Suryakancana University. They stated that vlog is a video blog that is similar to a text blog but with externally connected videos for each entry. Vloging can increase the intermediate and upper levels of education in speaking such as junior high school, senior high school or technical high school, and university. For the gathering the data they used interview and questionnaire and the results of them research that vlog can make students interested in learning, because vlog is a new instructional media for teachers and students; learning to speak through vlog is fun and not as boring as usual; students are more interested in learning to speak because vlog is a new instructional media for teachers and students. So, Video blog was recommended for further learning speaking for those who are willing to develop their speaking skills.

The previous researcher can be used as the references for this one study cases. This study can be different a variety of viewpoints on using vlog to improve English fluency and provide students with opportunities to practice public speaking. Finally, this research intends to see how vlog are effective as innovation in learning tools.

\section{Research Methodology}

This research used a qualitative method, in the finding data used the descriptive analysis. In the instruments, the researcher used observation to gain the most information according to students' performance in using vlog. And the participants are the students of SMP Darul Ulum Depok in eighth grader graduate.

During the observation, there are numerous stages to be conducted this research. The first are overview and planning, second is the progress and the third is evaluation (Roifah, 2020). For the first, the Students must understand more deeply about vlog and how the concept that they will create. Second, making progress in conducting vlog with a predetermined theme "Tell people or things or animals around us" in their environment, such as in the school or home environment or wherever they are. Third, after the students make a vlog, the students will be given to the teacher as the collecting 
the task. And the teacher will evaluate it with various aspects of the assessment to be followed: pronunciation, fluency, vocabulary, expression and good performance. Then the teacher gives feedback for students' performance in the future.

\section{Result and Discussion}

The result and discussion on the participants of eighth grader graduate at SMP Darul Ulum Depok in the showed their vlog have several summarized as follow:

1. Fluency

All students have an increase in fluency in vlog. They more able to express their abilities well and fluently. Which certainly enjoys more in terms of delivery. Does not make their feel scared when speaking directly. Previously, if there were confronted directly without using vlog, they would be nervous and stutter in their delivery. It was not clear what they meant. But when using the vlog, the content of vlog can be conveyed well.

2. Pronunciation

The students' pronunciation by using the vlog is clear. They communicate with a big voice without thinking of shame. But there still some people not suitable in intonation.

3. Vocabulary

The vocabulary of the students' vlog are adequate. They use the appropriate vocabulary for the content. In using vlog, students further improve their vocabulary with great levels.

4. Expression

During the vlog, students felt very passionate in expression. When they describe person/things/animals in their environment.

\section{Good Performance}

On the students' performance. They more enthusiastic in their confident and speak in natural manner. They seem to animate the whole of vlog. They not nervous in front of the camera. So, it shows they have good performance in the vlog.

The results demonstrate that using vlog as an innovation in learning to improve students' fluency and speaking skill has a good influence on the students. The use of a vlog encourages pupils to speak more. But, they should learn more to improve in learning vlog.

\section{Conclusion}

Vlog is one of innovation in learning English that can be improve to students speaking skill. In using vlog can be a fun and exciting way to learn. Furthermore, students can learn how to offer specific themes in public with good speaking skills. It can help pupils give a strong presentation when they speak. And they can gain confidence by speaking in front of other people. 


\section{BIBLIOGRAFI}

Andini, Tresna Nur, Eun, Lee Ye, Khramova, Alina, \& Żok, Alicja. (2020). ELT Comparison: Increasing Students Speaking Ability in Indonesia, South Korea, Russia, and Poland. English Language in Focus (ELIF), 2(2), 131. Google Scholar

Anggraini, Dewi. (2018). Chain Drill Technique in Teaching Speaking. Channing: English Language Education and Literature, 3(1), 51-59. Google Scholar

Butar, A. T., Sudarsono \&. Zainal Arifin. (2019). Video Blogging to Improve Students' Speaking Performance. Jurnal Pendidikan Dan Pembelajaran Khatulistiwa, 1(1), 41-57. Google Scholar

Lidya, Marina, \& Amir, Melvina. (2017). Classroom Discussion: an Activity To Promote Speaking in a Foreign Language. Tell-Us Journal, 2(2), 95-101.

Lingga, Yulima Melspia, Yulianti, Wan, \& Ningsih, Yuliana. (2021). Improving English Speaking Skill of EFL Class by USing Video Blog on Social Media. Journal of Applied Linguistics and Literacy, 5(1), 1-36. Google Scholar

Mandasari, Berlinda, \& Aminatun, Dyah. (2020). Improving Students' Speaking Performance Through Vlog. English Education: Journal of English Teaching and Research, 5(2), 136-142. Google Scholar

Marzuki, Muhammad Jahid, Jabu, Baso, \& Basri, Muhammad. (2018). The use of digital Vlog Media to enhance students 'speaking skill. Journal Pendidikan. Google Scholar

Matius, Gana, Haryanto, \& Salija. (2018). Teachers' Strategies in Teaching Speaking (a Case Study of an English Teacher in Sma Negeri 1 Toraja Utara). Teachers' Strategies in Teaching Speaking, 1-10. Google Scholar

Putri, Rasari Triani. (2018). An Analysis of Students' Speaking Grammatical Errors at The Second Grade SMAN 10 Jambi Academic Year 2017/2018. Journal of Materials Processing Technology, 1(1), 1-8. Google Scholar

Rahayu, N. Nurviyani. (2018). A Study oF Students' Speaking Skill Through Vlog. Hal 99-117 Vol 6, No 2. Google Scholar

Rizqiningsih, Shelawati, \& Hadi, Muhamad Sofian. (2019). Multiple Intelligences (MI) on Developing Speaking Skills. English Language in Focus (ELIF), 1(2), 127. Google Scholar

Roifah, Miftahur. (2020). Vlog As Learning Media to Train English Fluency and Public Speaking Skill. 14(1), 45-56. Google Scholar

Saputro, Teguh Hadi, Tafsirudin, Ibnu Choirin, \& Farah, Rafika Rabba. (2020). The Use of Vlog in Improving Students ' Oral Language Production : A Case Study. 13(1), 
135-158. Google Scholar

Sugiono, Shiddiq, \& Irwansyah, Irwansyah. (2019). Vlog Sebagai Media Storytelling Digital Bagi Tokoh Publik Pemerintahan. Jurnal Studi Komunikasi Dan Media, 23(2), 115. Google Scholar

Sumiharsono, Rudy dan, \& Hasanah, Hisbiyatul. (2017). Media Pembelajaran: Buku Bacaan Wajib Dosen, Guru dan Calon Pendidik - Rudy Sumiharsono, Hisbiyatul Hasanah - Google Buku. Cetakan Pertama, pp. 1-6. Google Scholar

\section{Copyright holder:}

Ainan Salsabila (2021)

First publication right:

Syntax Idea

This article is licensed under:

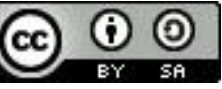

